\title{
Effect of a technological program for motor educational on the development of fundamental motor skills and some Emotional, social variables for the pre-school "Dr/ Rehab Adel Gabal
}

\section{Abstract}

The study aimed to design a proposed program for motor education using multimedia (a technological program for motor educational) and monitor its effects on the development of fundamental motor skills and some emotional, social variables for the pre-school. The researcher used the experimental method by the experimental design of two groups, one experimental and the other controlled using pre-post measurements for each group. the study was conducted on a sample of 40 pupils of the kindergarten stage with $72.73 \%$ of the total population in $2017 / 2018$, results indicated that the technological program for motor educational using multimedia technique led to the development of fundamental motor skills, the emotional variables and social variables under research compared to the traditional method in teaching (explanation and presentation method).

Keywords:Technological program, Multimedia, Fundamental motor skills, Emotional variables, Social variables, Pre-school.

\section{Introduction}

The technology is at the forefront of science, which seeks to develop its content and concept from time to time, according to the changes of the modern era, which is characterized by the revolution of information and knowledge and technology in various fields, especially the scientific and educational field, which is developing on a daily basis. [51]

Laurillard, Reiser et al (2017) pointed out that one of the strengths of the definition of education technology is that it focuses on systematic processes and the use of technological resources

"Assistant professor at department of curriculum, teaching methods, training and sport movement science. faculty of P.E, University of Sadat Cit, Egypt. 
and human

performance technology. It also focuses on the analysis of education, performance problems, design, development, use, evaluation and management of educational and noneducational processes and resources, Institutions. The new concept of education technology has been linked to the field of teaching design and technology, such as multimedia. [27][46]

Multimedia is the field concerned with the computercontrolled integration of text, graphics, drawings, still and moving images (Video), animation, audio, and any other media where every type of information can be represented, stored, transmitted and processed digitally. [13]

Multimedia finds its application in various areas including, but not limited to, advertisements, art,educatio $\mathrm{n}$, entertainment, engineering, medicine, mathematics, busine ss,

scientific research and spatial temporal applications. Several examples are as follows:

* Education. In education, multimedia is used to produce computer-based training courses (popularly called CBTs) and reference books like encyclopedia and almanacs. A CBT lets the user go through a series of presentations, text about a particular topic, and associated illustrations in various information

formats. Edutainment is the combination of education with entertainment, multimedia entertainment. * Education technology Multimedia provides students with an alternate means of acquiring knowledge designed to enhance teaching and learning through various mediums and platforms. This technology allows students to learn at their own pace and gives teachers the ability to observe the individual needs of each student. [5][12][32]

* Social work (social variables) and the emotional variables In an attempt to examine the impact of multimedia technology on students' study, A. Elizabeth Cauble \& Linda P. Thurston conducted a research in which Building Family Foundations (BFF), an interactive multimedia training platform, was utilized to assess social work students' reactions 


\section{4}

to multimedia technology on variables of knowledge, attitudes, and self-efficacy. The results states that respondents show a substantial increase in academic knowledge, confidence, and attitude. Multimedia also benefits students because it brings expert to students online, fits students' schedule, allows students to choose courses that suit them. [7][11]

\section{Mayer's Cognitive}

Theory of Multimedia Learning suggests, "people learn more from words and pictures than from words alone." According to Mayer and other scholars, multimedia technology stimulates people's brains by implementing visual and auditory effects, and thereby assists online users to learn efficiently. Researchers suggest that when users establish dual channels while learning, they tend to understand and memorize better. Mixed literature of this theory are still present in the field of multimedia and social work. [7][11][23]

On the other hand, fundamental motor skills are movement patterns that involve various body parts and the foundational movements. Examples are crawling, walking, running, hopping, jumping, bending, pushing and pulling, binding, extension, tweeking, rotation, bouncing, balance, galloping and skipping.[28]

Through the practical observation and supervision of practical education schools and observing the motor performance of the pupils, the researcher noted weakness, lack of fundamental motor skills such as walking, running and jumping. Also, fundamental motor skill's performance level for the pupils in is characterized by randomness, poor performance and lack of coordination in motor sequence, which called on the researcher to design a technological program for motor educational and monitor its effects on the development of fundamental motor skills and some emotional, social variables. Thus, using of education technology in the development of fundamental motor skills.

Therefore, this study is an attempt to using one of the most modern techniques in the field of motor educational, by 
designing a technological program using multimedia for study its effect on the development of fundamental motor skills and some emotional, social variables.

\section{Reseach Aim:}

The main aim of this study was designing a technological program for motor educational (a motor education program using multimedia) and monitor its effects on the development of fundamental motor skills (walking, running, jumping, hopping, balance, throwing, catching, kicking), the emotional variables and social variables.

\section{Research hypothesis:}

1. There are statistically significant differences between the pre-and post-measurements for experimental group (multimedia group) in the motor, emotional and social variables under research in favor to the post measurement.

2. There are statistically significant differences between the pre-and post-measurements for the controlled group (explanation and presentation group) in the motor, emotional and social variables under research in favor to the post measurement.

3. There are statistically significant differences in post measurements between the two experimental, controlled groups in the motor, emotional and social variables under research in favor to the experimental group (multimedia group).

\section{Methodology \\ Method:}

The

experimental approach was used for two groups, one experimental and the other controlled, using prepost measurements for each group for the pre-school.

\section{Research sample:}

The research society consisted of (55) pupils of the pre-school $\left(\mathrm{KG}_{2}\right)$ in School of Abu-Bakr Al-Siddiq - City Sadat for the year 2017/2018. The basic sample was randomly selected from the pupils of the research society. The total number of the sample was (40) pupils with $72.73 \%$ of the total population, and the sample was divided as follows; Experimental group: uses the motor educational program using multimedia, (20) pupils. Controlled group: uses the motor educational program using the traditional method 
"explanation and presentation style", (20) pupils.

And (15) pupils of the total research community and outside the basic research sample as exploration sample. Thus, the basic sample and outside the basic research sample consisted of (55) pupils by $100 \%$ of the population.

\section{Tools:}

\section{1- Data recording forms:} (Appendix 1): Forms for recording the measurements and data for the sample: name, age, height, weight, scores of IQ test, fundamental motor skills, emotional variables and social variables under research. 2- Tools and devices: Restameter device for measuring height and weight, tools of motor educational (collar, rope, sand bottles, grain bags, sandbags, stick, balls, parachute, tennis balls).

3- IQ test (Appendix 2): The "Man Drawing for Children's Intelligence" test was used by American researcher

Goodnough F. Translation of "Mohamed Farrag, AbdelHalim Mahmoud, Safia Mohammadi 1998" [20:97,98], After the establishment of "Harris A." By making some modifications, it became known as the Goodnough Harris Drawing Test to be the child's assessment of the child's observation and the evolution of his perception of the subject rather than on the basis of artistic skill in the drawing.

\section{4- Evaluation form of} fundamental motor skills: The form was used evaluation of fundamental motor skills, prepared by R. Gabal, Ayat Mohamed and A. Khalil 2014 (Appendix 3). The form was purposed to evaluation of fundamental motor skills under research for the pre-school. The form was prepared in 2014 through the following references: (Rehab A. et al., 2014), (Zeinab, Ghada 2010), (Abdallah A., Rehab A. 2014), (Essam 2014), (Ministry of Education 2012a,b), (Amin et al., 1998), (Khairya, AbdelWahab 2005) and (Khairya, Waseela and Fatma 2005). [2] [4] [17] [25] [26] [34] [35] [44] [57]

The number of phrases reached (86) phrases. The form was presented to the experts at the faculties of physical education (appendix4) for the purpose of identifying the experts' opinion. The percentage of the experts' 
agreement was calculated on phrases of the form. The agreement rates on the phrases ranged from $75 \%$ to $100 \%$.

5- Test of Emotional variables, Social variables(Appendix 4): The degree of emotional and social variables for pre-school students was measured by tests emotional and social variables, prepared by Rehab Gabal 2011 (Appendix 3). The objective of the two tests was to identify the degree of emotional and social aspects of pre-school students. Preparation of the tests in 2011 through the following references: (Rehab A. Gabal 2011b), (Bold P. 2010), (Sahar 2005), (Samira 2003), (Sayed 2010), (Nermin 2008), (Wael 2008) and (Green 2010). [9] [21] [41] [47] [48] [49] [39] [53] [57]

\begin{tabular}{|c|}
\hline \\
\hline \\
\hline \\
\hline \\
\hline \begin{tabular}{lll} 
The & \multicolumn{2}{c}{ technological } \\
program & for & motor \\
educational & (program of of \\
motor education using
\end{tabular} \\
\hline
\end{tabular}

The technological program for motor educational (program of motor education using multimedia) was designed as shown below:

- Defining the aim of the program that suits its content: (Designing a program of motor education using multimedia to know its effect on on the development of fundamental motor skills and some emotional, social variables) for the pre-school.

- The educational content was analyzed through the curriculum of the pre-school or Kindergartens (Ministry of Education 2012a,b) [34] [35], In addition the following references that describing the fundamental motor skills under research: (Rehab A. et al., 2014), (Zeinab, Ghada 2010), (Abdallah A., Rehab A. 2014), (Essam 2014), (Ministry of Education 2012a,b), (Amin et al., 1998), (Khairya, AbdelWahab 2005) and (Khairya, Waseela and Fatma 2005), which was used when designing the technological program for motor educational (multimedia program). [2] [4] [17] [25] [26] [35] [36] [41] [44] [57]

- The researcher prepared (24) technological units using Visual Basic language to have the opinion of experts about the appropriateness of these units. The experts approved the distribution of program content (technological units of motor 
educational program) by $100 \%$ as shown in Table (5).

- The importance of the technological program content of the sample was clarified, taking into account the grading factor in the design of the program. using Visual Basic software as shown in both (CD-ROM and appendix 6) This point included the following:

* The program's main screens: Containing the introduction which clarifies idea and title of the technological program for

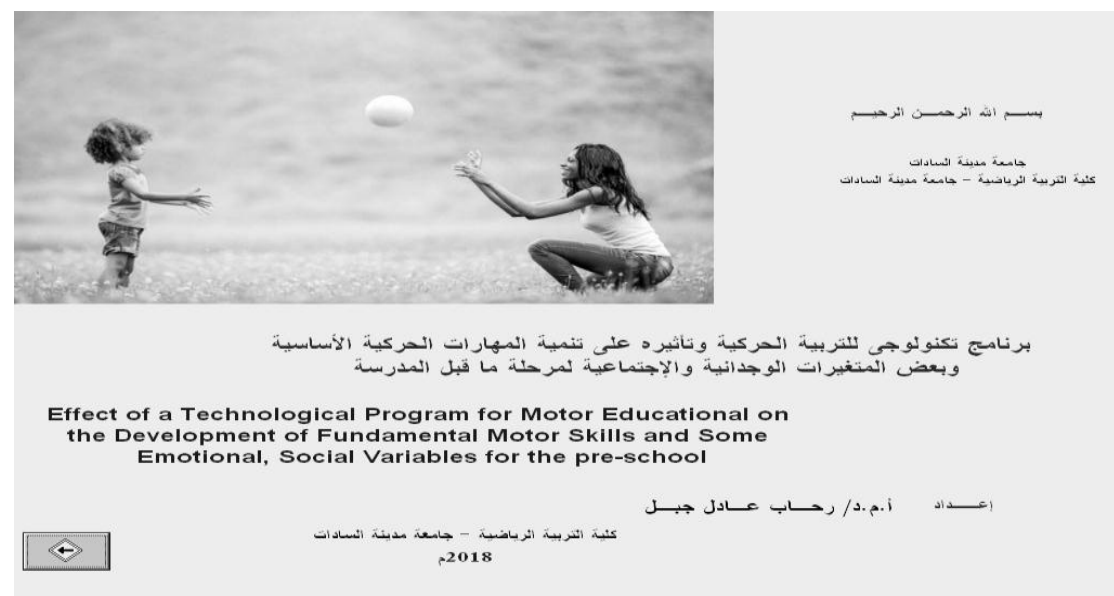

- The technological program for motor educational display motor educational using was organized under research

The second, the third, the fourth and the fifth screen (Appendix 6).

- The experts' opinion of the program (appendix 7) was reviewed and its appropriateness for the sample and agreement was obtained on the validity of a multimedia program of fundamental motor skills.

- The proposed program was tested on a sample of the

\section{multimedia.}

exploratory study to determine the suitability of the multimedia program for the sample. This experiment resulted in the clarity of all the contents of the multimedia program to the sample pupils of the exploratory study.

\section{Application of the program:}

The motor educational program using both of multimedia, explanation and 
presentation style was implemented on the basic study sample (40 pupils) according to the time distribution, as shown in appendix (5).

- The time distribution of the program was standardized for the two research groups, and

\section{Table (1)}

the difference was only in the learning method for each group. The experimental group was learn by multimedia program. The controlled group was through explanation and presentation style.

Result

Significance of the mean differences between the (pre- post) measurements of the experimental group in the parameters under research

\begin{tabular}{|c|c|c|c|c|c|c|}
\hline \multirow[b]{2}{*}{ Parameters } & \multicolumn{4}{|c|}{$\begin{array}{c}\text { Experimental } \\
\text { (Multimedia) } \mathrm{N}_{\mathrm{t}}=20\end{array}$} & \multirow{2}{*}{$\begin{array}{c}\text { Mean } \\
\text { Differences }\end{array}$} & \multirow{2}{*}{$\begin{array}{c}\mathrm{T} \\
\text { value }\end{array}$} \\
\hline & \multicolumn{2}{|c|}{ Pre } & $\begin{array}{c}\text { Post } \\
\mathbf{M}\end{array}$ & $+\mathrm{SD}$ & & \\
\hline \multicolumn{7}{|c|}{ Fundamental motor skills: } \\
\hline Walking & 22.55 & 2.79 & 28.99 & 3.22 & 6.44 & $9.58 *$ \\
\hline Running & 41.10 & 2.15 & 44.66 & 2.74 & 3.56 & $6.04 *$ \\
\hline Jumping & 20.62 & 1.98 & 30.63 & 3.64 & 10.01 & $14.53 *$ \\
\hline Hopping & 20.45 & 1.68 & 26.75 & 2.06 & 6.30 & $8.89 *$ \\
\hline Balancing & 15.85 & 1.72 & 25.69 & 2.65 & 9.84 & $12.41 *$ \\
\hline Throwing & 27.88 & 2.12 & 35.62 & 3.33 & 7.74 & $10.06^{*}$ \\
\hline Catching & 19.65 & 1.25 & 25.41 & 3.29 & 5.76 & $8.04 *$ \\
\hline Kicking & 8.50 & 1.01 & 13.88 & 2.54 & 5.38 & $7.74 *$ \\
\hline Emotional variables & 15.23 & 4.91 & 22.70 & 5.76 & 7.47 & $9.96 *$ \\
\hline Social variables & 13.41 & 4.56 & 20.17 & 5.25 & 6.76 & $8.76 *$ \\
\hline
\end{tabular}

$\mathrm{T}$ Table value at a significant level $(19,0.05)=1.73$ (one direction) Table (1) shows experimental group at a statistically significant differences between Pre-Post measurements of the significant level of 0.05 in favor to the post measurement. 
Table (2)

Significance of the mean differences between the (pre- post) measurements of the controlled group in the parameters under research

\begin{tabular}{|c|c|c|c|c|c|c|}
\hline \multirow{3}{*}{ Parameters } & \multicolumn{4}{|c|}{$\begin{array}{c}\text { Controlled } \\
\text { (Explanation and presentation) } \\
\mathrm{N}_{₹} 20\end{array}$} & \multirow{3}{*}{$\begin{array}{c}\text { Mean } \\
\text { Differences }\end{array}$} & \multirow{3}{*}{$\begin{array}{c}\mathrm{T} \\
\text { value }\end{array}$} \\
\hline & \multicolumn{2}{|c|}{ Pre } & \multicolumn{2}{|c|}{ Post } & & \\
\hline & $\mathbf{M}$ & \pm SD & $\mathbf{M}$ & \pm SD & & \\
\hline \multicolumn{7}{|c|}{ "Fundamental motor skills: } \\
\hline Walking & 22.62 & 2.82 & 26.41 & 3.10 & 3.79 & $7.02 *$ \\
\hline Running & 41.06 & 2.14 & 42.55 & 2.35 & 1.49 & $3.30^{*}$ \\
\hline Jumping & 20.55 & 1.97 & 25.86 & 2.43 & 5.31 & $7.40^{*}$ \\
\hline Hopping & 20.50 & 1.71 & 23.87 & 1.89 & 3.37 & $6.09^{*}$ \\
\hline Balancing & 15.91 & 1.74 & 20.58 & 2.01 & 4.67 & $7.55^{*}$ \\
\hline Throwing & 27.83 & 2.08 & 31.34 & 2.71 & 3.51 & $5.86^{*}$ \\
\hline Catching & 19.61 & 1.24 & 22.94 & 1.40 & 3.33 & $6.05^{*}$ \\
\hline Kicking & 8.53 & 1.02 & 10.88 & 1.42 & 2.35 & $4.57 *$ \\
\hline Emotional variables & 15.20 & 4.90 & 18.69 & 4.98 & 3.49 & $6.22^{*}$ \\
\hline Social variables & 13.52 & 4.58 & 17.05 & 5.06 & 3.53 & $6.41^{*}$ \\
\hline
\end{tabular}

T Table value at a significant level $(19,0.05)=1.73$ (one direction) Table (2) shows group at a significant level of statistically significant 0.05 in favor to the post differences between Pre-Post measurement. measurements of the controlled

Table (3)

Significance of the mean differences between the (post-post) measurements of the two groups (experimental, controlled) in the parameters under research

\begin{tabular}{|c|c|c|c|c|c|c|}
\hline \multirow{3}{*}{ Parameters } & \multicolumn{4}{|c|}{ Post measurement $\mathrm{N}=40$} & \multirow{3}{*}{$\begin{array}{c}\text { Mean } \\
\text { Differences }\end{array}$} & \multirow{3}{*}{$\begin{array}{c}\mathrm{T} \\
\text { value }\end{array}$} \\
\hline & \multicolumn{2}{|c|}{ Experimental } & \multicolumn{2}{|c|}{ Controlled } & & \\
\hline & M & \pm SD & $\mathbf{M}$ & \pm SD & & \\
\hline \multicolumn{7}{|c|}{ Fundamental motor skills: } \\
\hline Walking & 28.99 & 3.22 & 26.41 & 3.10 & 2.58 & $4.55^{*}$ \\
\hline Running & 44.66 & 2.74 & 42.55 & 2.35 & 2.11 & $4.48^{*}$ \\
\hline Jumping & 30.63 & 3.64 & 25.86 & 2.43 & 4.77 & $7.89^{*}$ \\
\hline Hopping & 26.75 & 2.06 & 23.87 & 1.89 & 2.88 & $4.78^{*}$ \\
\hline
\end{tabular}


Follow Table (3)

Significance of the mean differences between the (post-post) measurements of the two groups (experimental, controlled) in the parameters under research

\begin{tabular}{l|c|c|c|c|c|c}
\hline \hline \multirow{2}{*}{ Parameters } & \multicolumn{4}{|c|}{ Post measurement $\mathrm{N}=40$} & \multirow{2}{*}{$\begin{array}{c}\text { Mean } \\
\text { Differences }\end{array}$} & \multirow{2}{*}{$\begin{array}{c}\mathrm{T} \\
\text { value }\end{array}$} \\
\cline { 2 - 5 } & Experimental & \multicolumn{2}{c|}{ Controlled } & \\
\cline { 2 - 5 } & $\mathbf{M}$ & \pm SD & $\mathbf{M}$ & \pm SD & & \\
\hline \hline Balancing & 25.69 & 2.65 & 20.58 & 2.01 & 5.11 & $7.95^{*}$ \\
\hline Throwing & 35.62 & 3.33 & 31.34 & 2.71 & 4.28 & $7.40^{*}$ \\
\hline Catching & 25.41 & 3.29 & 22.94 & 1.40 & 2.47 & $4.50^{*}$ \\
\hline Kicking & 13.88 & 2.54 & 10.88 & 1.42 & 3.00 & $5.29^{*}$ \\
\hline Emotional variables & 22.70 & 5.76 & 18.69 & 4.98 & 4.01 & $7.25^{*}$ \\
\hline Social variables & 20.17 & 5.25 & 17.05 & 5.06 & 3.12 & $5.38^{*}$ \\
\hline \hline
\end{tabular}

T Table value at a significant level $(38,0.05)=1.69$ (one direction) Table (3) shows fundamental motor skills, the statistically significant differences in post measurements between the two groups (experimental, controlled) at a significant level of 0.05 in favor to the experimental group.

\section{Discussion}

First research hypotheses: (Multimedia)

The results of Table (1) show that there are statistically significant differences between pre and post mean values of the experimental group where the lowest value of calculated $(\mathrm{t})$ (6.04) it was greater than the value of table (t) (1.73) at a significant level (0.05) in favor to post measurement, which indicates the higher level of emotional variables and social variables under research for the post measurement to the experimental group (multimedia group).

The researcher attributes the level of progress and improvement in these results to the experimental variable only, which is the use of the multimedia method in the development of the fundamental motor skills, the emotional variables and social variables under research. This indicates that the presentation of program in the multimedia method has a positive effect on the skills under research and knowledge of the fundamental motor skills content through 
multimedia and information that helps to form a clear picture by text, sound and image of this skills (fundamental motor skills).

This indicates that using multimedia has a positive effect on the fundamental motor skills of pupils. Which is consistent with the study of (Medina 2016), (Jean, Charles 2015), (Smorzewska 2015), (Talha 2011), (Rehab 2011a), (Rehab, Duaa 2015), (Eman 2014), (Ayat, Eman 2016), (Rehab, Abdallah and Khaled 2013), (El-Banna 2017), (AbdRabbo 2015), (Abdallah 2016), (Rehab 2016), These studies indicated that the computer groups based on the use of multimedia method have a positive effect on the skillful, motor, emotional or social variables under research. [1] [3] [6] [16] [19] [24] [31] [33] [40] [42] [43] [45] [50]

Thus, the first hypothesis is achieved, which stated that there are statistically significant differences between the pre-and post-measurements of the technological program group for motor educational (using multimedia) in the development of the motor, emotional and social variables under consideration in favor to the post measurement.

\section{Second research hypotheses (explanation and presentation method):}

The results of Table (2) show that there are statistically significant differences between pre and post measurement of the controlled group in development of fundamental motor skills, the emotional variables and social variables in favor to the post measurement.

These results indicate that the explanation and presentation style was a positive effect on development of variables under research (fundamental motor skills, the emotional variables and social variables). This indicates that the traditional method of education or instruction was led to pupils improvement in the information and concepts related to these variables. Thus, Improved and effective in emplement of fundamental motor skills, the emotional variables and social variables under research.

The previous results was indicated that the method of explanation and presentation leads to progress and 
improvement in the educational process, where the teacher relied on the explane of information and content understanding of the performance through verbal explanation and a model presentation of how to implement and this was led to effectiveness and positive on the fundamental motor skills, the emotional variables and social variables for the controlled group. This is consistent with Zakia Kamel, Nawal Shaltout andMervat Khafaja (2010), Rehab Gabal (2016), Eman Abdel-Halim (2014, 2018) and Ayat, Eman (2016) where they pointed out that the method of explanation and presentation has a positive effect on the development of skills under research. [6] [15] [16] [42] [57]

Therefore, the second hypothesis is achieved, which stated that there are statistically significant differences between the pre-and post-measurements for the controlled group (explanation and presentation group) in the development of fundamental motor skills, the emotional variables and social variables in favor to the post measurement.

\section{Third research hypotheses:}

The results of Table (3) show that there are statistically significant differences in post measurements between the two groups (experimental, controlled) in the development of fundamental motor skills and some emotional, social variables for the experimental group where the lowest value of calculated (t) (4.48) it was greater than the value of table (t) (1.69) at a significant level (0.05), which indicates the higher level of the fundamental motor skills and emotional, social variablesunder consideration for the experimental group (multimedia group) than the controlled group (explanation and presentation).

This indicates that the progress in the variables level under research of the experimental group compared to the controlled group is due to the reliance on the multimedia program and the diversity of images, sound, music and video, thus the positive effect on the level of the fundamental motor skills and some emotional, social variables due to the 
attractiveness and effectiveness of the multimedia program.

The researcher attributed the reason for the preference of the multimedia group compared to the explanation and presentation group that the pupils of the experimental group (multimedia) had the opportunity to imagine the correct performance free of errors because of using images, sound, music and video when watching the skills under research on the Computer (multimedia program) where they were briefed on the best technical aspects of the fundamental motor skills which was reflected positively on the performance level of the experimental group compared to the controlled group (explanation and presentation method), and the above is consistent with (Magdy 2003), (Moustafa 2009), (Yaseen 2006), (Yogesh 2004) and (Mohamed, Makarem, Hany, 2001). [30] [36] [37] [54] [55]

The above is consistent with the study both of Abdallah (2016) and Chastre, Edouard (2015), which indicated that the using of multimedia and technology in general in the educational process has effective in learning the skills under research because of the attractiveness and effectiveness of multimedia e-studies compared to others traditional methods. [1][24]

Therefore, the third hypothesis is achieved, which stated that there are statistically significant differences in post measurements between the experimental and controlled groups in the level of fundamental motor skills, the emotional variables and social variables under consideration in favor to the experimental group (multimedia group).

\section{Conclusion}

- The multimedia program has a positive effect on the development of fundamental motor skills, the emotional variables and social variables under research for pre-school.

- The traditional method in teaching or instruction (the explanation and presentation style) has a positive effect on the development of fundamental motor skills, the emotional variables and social variables under research for pre-school.

- The technological program for motor educational (multimedia program) led to a 
higher level of fundamental motor skills, the emotional variables and social variables under research for pre-school compared to the explanation and presentation style.

Recommendations

- Encouraging using the technological program for motor educational (multimedia program) for pre-school pupils because of its effect in developmenting of fundamental motor skills, the emotional variables and social variables.

- Introducing programs designed through multimedia in the curricula of the preschools.

- The need to benefit from the expertise of specialists in the field of education technology by holding seminars and lectures in the educational institutions to raise awareness of the importance of using multimedia in the educational process.

\section{References}

1- Abdallah Abdel-Halim Mohamed:Effects of Technology Programes (threedimensional models technique and multimedia) on Skillful Learning in Volleyball, Assiut Journal of Sport Sciences and
Arts, Volume 4, December 2016.

\section{2- Abdallah Abdel-Halim} Mohamed, Rehab Adel Gabal: Teaching in the light of the contemporary reality of sports education (concepts, principles, applications), World Sports Foundation for publishing and Dar Al-Wafaa for printing, $3^{\text {rd }}$, Alexandria 2014.

\section{3- Ahmed Talha Hossam El-}

Din: "Using E-learning in learning the subject of teaching methods" Unpublished Master thesis, Faculty of Physical Education, Sadat University 2011.

4- Amin Anwar Al-Khouly, Mahmoud Abdel-Fattah Annan, Adnan Darwish Galon: School Physical Education, Guide to the teacher of the class and the practical education student, Dar Arab Al-Fikr for Publishing, 4 edition, Cairo 1998.

5- Andresen and Brink, Brent and Katja:"Multimedia in Education Curriculum" (PDF). United Nations Educational, Scientific and Cultural Organizaiton: 140 via Google Scholar, 2013.
6- Ayat
Abdel-Halim Mohamed Aly, Eman Abdel- 
Halim Mohamed Aly: The effect of different Teaching Styles on Learning some Volleyball Skills for Female P.E Students (Comparative Study). The international scientific Journal of Physical Education and Sport, Sciences, NSSN 24003, Print issn: 2356/9565, Online issn: 2356/9573, Volume (3), 98106, Faculty of Physical Education, Helwan University, January 2016.

7- Ballantyne, Neil:

"Multimedia Learning and Social Work Education" Social Work Education. 27: 613622.doi:10.1080/02615470802 201655, September 2008.

8- Benjamin Herold: Technology in Education, An Overview, Blended Learning: Breaking Down Barriers (Education Week special report), at https://translate. google.com.eg/translate?hl=ar $\& s l=e n \& u=h t t p s: / / w w w . e d w e e$ k.org/ew/issues/technology-ineducation/index.html\&prev=se arch, Published: February 5, 2016.

9- Bold P.: Developmental Psychology, Lecture Notes, Social\&Emotional

Development in Early Childhood, University of South
Florida, DEP4005-Spring, 2010,ww.cas.usf.edu

10- Carol Smith: Introduction to Multimedia, Definition of Multimedia, at https://www. slideshare.net/azira96/chapter1-introduction-to-multimedia, Published on Oct 10, 2015.

\section{1- Cauble, Elizabeth;} Thurston, Linda: "Effects of Interactive Multimedia Training on Knowledge, Attitudes, and Self-Efficacy of Social Work Students". Research on Social Work Practice.10: 428-437, 4 July 2000.

12- Collis, Betty.

"Anticipating the Impact of Multimedia in Education: Lessons from the Literature" (PDF). Computers in Adult Education and Training - via Google Scholar. 13- Dave Marshall: A Multimedia Application at https://users.cs.cf.ac.uk/Dave.

Marshall/Multimedia/node10.h tml, 5 January 2018.

\section{4- David Roberts:}

Loughborough University, Academia.edu".lboro.academia .edu. Retrieved 2017-01-18.

\section{5- Eman Abdel-Halim} Mohamed: Effectiveness Using of Flipped Learning Strategy on Some Skillful 
Learning Aspects of Physical Education Lesson, Journal of Applied Sports Science (JASS), Faculty of Physical Education, Issue 91, Faculty of Physical Education in Abu Qir, Alexandria University, 2018.

\section{6- Eman Abdel-Halim}

Mohamed: "Program design using multimedia and its impact on the outcomes of practical teaching methods learning course for students of the Faculty of Physical Education" unpublished doctoral thesis, Faculty of Physical Education in Gezera, Helwan University 2014.

\section{7- Essam El-Din Metwally} Abdallah: Methods of teaching physical education between theory and practice, the world of sports publishing and Dar Al-Wafa for printing, Alexandria 2014.

18- Facer, K. \& Sandford, R.: The next 25 years?: Future scenarios and future directions for education and technology . Journal of Computer Assisted Learning, 26, 7493 . doi: 10.1111/j.13652729.2009.00337.x [Crossref], [Web of Science ${ }^{\circledR}$ ], [Google Scholar], 2010.

19- Fatma Mohamed AbdRabbo: "The effectiveness of a proposed motor education program for the development of environmental values and environmental behavior of the primary stage" unpublished doctoral thesis, Faculty of Physical Education for girls in Gizera, Helwan University 2015.

20- Goodnough Florence, Harris Allan: The Man's Drawing Test, Translated by Mohamed Farghaly Farrag, Abdel-Halim Mahmoud, Safya Mohamadi, Factor Kirlos Press, Pages (97,98), Cairo 1998.

21- Green J.C Auther. The effect of ten wek physical fitness program of profiles. Journal Coucil for health physical education, Sport \& dance, pp42-47. 2010.

22- Hayword T.: Advemtures In Virtual Reality Compased In chetten Ham And Mpc Digital by Prentice Hall Computer, Publishing by Our Carparation, Modison, Wisconsim, Dubuque, Lower. 2003.

23- Irby, Beverly; Brown, Genevieve; LaraAiecio, Rafael; Jackson, Dr. Shirley: Handbook of Educational Theories. IAP.ISBN 9781617358678, March 1, 2013. 
24- Jean Chastre, Charles-

Edouard Luyt: Factors affecting the e-learning outcomes, Telematics and Informatics, Volume 32, Issue 4, November 2015, Pages 701719.

25- Khairya Ibrahim AlSukkari, Mohamed AbdelWahab Mohamed: Sport programs for kindergartens, Dar Al Ma'arif, second edition,Cairo 2005.

26- Khairya Ibrahim AlSukkari, Waseela Mohamed Mahran, Fatma Fawzi Abdel-Rahman: Basic Skills in Physical Education for Kindergartens "Special Needs" Dar Al-Wafa, Alexandria 2005. 27- Laurillard, D.: Rethinking university teaching.A conversational framework for the effective use of learning technologies (3nd ed. ). London : Routledge Falmer. [Crossref], [Google Scholar], 2017.

28- Lindsay Broomfield: Human Kinetics, Fundamental movement skills provide the basis of physical literacy, at http://www.humankinetics.com /excerpts/excerpts/fundamental -movement-skills-provide-thebasis-of-physical-literacy--- complete-guide-to-primarygymnastics, April 2018.

29- Lorraine Lafrenière:The NCCP Fundamental Movement Skills Workshop, TeamSnap, Coaching Association of Canadaat https://www.coach. $\mathrm{ca} /$ fundamental-movementskills-s16736, Ottawa, K1H 7X7, Canada, April 2018.

30- Magdy Aziz Ibrahim: Education Strategies and Learning Methods, The Anglo Egyptian Library, Cairo 2003.

31- Mahmoud Moustafa ElBanna: "Effectiveness of the active learning strategy through the information network and its impact on some of the motor skills in the lesson of physical education" Unpublished Master thesis, Faculty of Physical Education, Banha University 2017.

32- Malik and Agarwal, S.: "Use of Multimedia as a New Educational Technology ToolA Study" (PDF).International Journal of Information and Education Technology. 2 - via Google Scholar. line feed character in |title $=$ at position 50 (help), October 2012.

33- Medina John: Active Education, Growing Evidence on Physical Activity and Academic Performance, at 
http://www.supportrealteachers .org/articles-on-physicaleducation-physical-activity-academic-achievement.html, Physical Educator, 64(3), 2016. 34- Ministry of Education: Educational applications (second level): play and learn and innovate, the book sector, Modern Al-Sherook Press, at http://dryasser73islam.ahlamou ntada.com/t27132-topic, Cairo 2012b. 1-74.

35- Ministry of Education: The tool of continuous evaluation: play and learn and innovate, the book sector, Modern Al-Sherook Press, at http://dryasser73islam.ahlamou ntada.com/t27132-topic, Cairo 2012a. 51-66.

36- Mohamed Saa'd

Zaghloul, Makarem Helmi Abu-Harja, Hany Said Abdel Moneim:

Education

Technology and Methods in Physical Education, Book Cente, 2nd Edition, Cairo 2001.

\section{7- Moustafa Abdel-Samie} Mohamed:

Educational

Technology, Arabic Studies, 2nd Edition, Book Center Publishing, Cairo 2009.

38- Moustafa Al-Sayeh Mohamed: The Technological Approach, Learning and
Information technology in Physical Education - Dar Al Wafa - Alexandria 2004.

39- Nermin Mahmoud Ahmed: "The relationship between the concept of reading self and the motivation of achievement in children with learning difficulties in the first of basic education" Unpublished MA thesis, Institute of Educational Studies, Cairo University 2008. 40- Rehab Adel Gabal: "Designing an educational program using the international information network and its impact on the implementation on the physical education lesson aspects in the light of the overall quality standards" Journal of Science and Sports Arts, Volume 39, Faculty of Physical Education in Gezera, Helwan Universityun, June 2011.

41- Rehab Adel Gabal:Effect of Using the International Information Network (Internet) on Improving Some Fundamental Motor Skills of the Intellectual Disabilities, World Journal of Sport Sciences "2186-WJSS", ISSN 2078 - 4724, University of Tehran, Volume (4), Number (3): $\quad 325-329, \quad$ at 
http://www.idosi.org/wjss/wjss 4(3)11.htm, http://www.idosi. org /wjss/4 (3)11/18.pdf, June 1, 2011.

42- Rehab Adel Gabal: Effectiveness of e-study on learning physical exercises and teaching formations, Assiut Journal of Sport Sciences and Arts,Faculty of Physical Education, Assiut university, December 2016.

43- Rehab Adel Gabal, Abdallah A. Mohamed and Khaled A. El-Battawy: "Effects of Teaching Strategy (cooperative learning and computer) on Learning the volleyball skills in P.E. Lesson". Journal of Physical Culture and Sport, Studies and Research, 24th of October 2013, Warsaw, Poland.

44- Rehab Adel Gabal, Ayat Abdel-Halim Mohamed and Abdallah Khalil: Comparative Study to Some Proposed programs Using Role-play, Movement Stories and Competitions Games and its Effects on Some Motor Skills for the Children of pre-School, Scientific Journal of Physical Education and Sports, Issue 71, Part II, Faculty of Physical Education for Boys, Helwan University, May 2014.
45- Rehab Adel Gabal, Duaa Hosny El Shalakany: "The Effect of an Educational Program Using the Computer on Learning Some Basic Skills in Volleyball for Middle School Girls in the Physical Education lessons" Journal of Applications of Sports Science, Issue 91, Faculty of Physical Education in Abu Qir, Alexandria University 2015.

46- Reiser, Woo Y .\& Reeves, TC.: $\quad$ Meaningful interaction in web-based learning: A social constructivist approach . Internet and Higher Education , $10,15-$

25 . doi:10.1016/j.iheduc. 2006 . 10.005, 2017.

\section{7- Sahar Mohamed}

Sha'ban: "Effectiveness of a guiding program to improve the self concept", Unpublished $\mathrm{PhD}$ thesis, Institute of Higher Studies for Children, Psychological and Social Studies, Ain Shams University, Cairo 2005.

\section{8- Samira Mohamed}

Ibrahim: "Self Concept and Psychological Consensus in Children", Unpublished MA Thesis, Faculty of Education, Ain Shams University, Cairo 2003. 
49- Sayed Ahmed ElToukhy: "A study of the relationship between the self concept and some attitudes of parents in the social upbringing of secondary school students" Journal of the Faculty of Education, Issue 12, Ain Shams University, Cairo 2010.

50- Smorzewska E.: Selected Examples of Interactive Teaching Methods in the Centre of Geoeducation in the City of Kielce (Poland). Social and Behavioral Sciences, Volume 173, Pages 214-220, 2015.

\section{1- Tamer El-Mallah:}

Education Technology, The New Concept and its Elements, Faculty of Education, Egypt, at https://www.new-educ.com/, 10 November 2017.

52- TEDx Talks: Visual feasts of the mind: matching how we teach to how we learn | David Roberts | TED xLoughboroughU, (2016-12-13), retrieved 201705-17.

53- Wae'l Abdel-Fattah Saber: "A study of the growth of the self concept in the light of some cultural and social variables", Unpublished MA thesis, Faculty of Education, Ain Shams University, Cairo 2008.

54- Yaseen Abdel-Rahman Kandil: Instructional aids and information technology, International Publishing House, 3rd Edition, Al-Riyad, Saudi Arabia 2006.

55- Yogesh Malhotra and Ranel E. Erickson: "Interactive Educational Multimedia": Coping with need for Innerving data Storage, Educational Technology, V. 34, No. 4, P. 35. 2004.

56- Zakia Ibrahim Kamel, Nawal Ibrahim Shaltout, Mervat Ali Khafaja: Fundamentals of Teaching Physical Education, Technical Radiation Press (Al-eshaa Press), 2nd edition, Alexandria 2010.

57- Zeinab Ali Omar, Ghada Galal Abdulhakim: Teaching methods of physical education "theoretical foundations and practical applications" Arab Thought House, Cairo 2010. 